\title{
The Use of Directed Reading Thinking Activity Strategy To Enhance Students' Reading Comprehension
}

\author{
Nelson Balisar Panjaitan ${ }^{1}$, Yohanes Luluando Siagian ${ }^{2}$ \\ 1,2 Universitas Advent Indonesia \\ nelson.panjaitan@unai.edu
}

\begin{abstract}
Teaching English reading in Indonesia is to develop comprehension skills. According to Andriani (2016), comprehension is the main goal of reading. In this study, the researcher wants to find out whether Directed Reading-Thinking Activity (DRTA) is a strategy that can guide students in asking questions about a text, making predictions, and then reading to confirm or refute their predictions to achieve the good and enhanced comprehension. And the process is to encourage the students to be active and thoughtful readers (Rahim, 2011). This study was designed to find out the answer to the following question: Is there any significant difference in reading comprehension achievement before and after giving DRTA treatment? The researcher used SPSS 21.0 to analyze the data. SPSS is a kind of computer program for statistically computation. It includes test of normalized gain, test of normality, test of variance homogeneity and test of mean difference or T-test. The level of significance $\square=0.05$ The result of the data showed that tests was normally distributed and it was also homogeneous. The researcher concluded that DRTA is an effective strategy in enhancing students' reading ability, because the hypothesis testing result showed that $\mathrm{p}$ value $(\mathrm{Sig})=0.000$, it means that $\mathrm{p}$ value $(\mathrm{Sig}$. $) \leq \alpha$ (0.05). It can be interpreted that $\mathrm{H} 0$ is rejected and $\mathrm{Ha}$ accepted.
\end{abstract}

Keywords: Reading Comprehension, Directed Reading-Thinking Activity

\section{INTRODUCTION}

English has been used in almost all countries in the world and has become an international language. Indonesia is one of the countries that also uses English. However, English in Indonesia is used as a foreign language (EFL). Since Indonesia's independence in 1945, English has been taught as a compulsory subject at schools. Based on the national curriculum in Indonesia (Kurikulum, 2004, 2003) english has been taught at junior secondary school. English is taught as a compulsory subject for three years in Grades 7-9. The teaching of English had been integrated in curriculums starting from secondary to tertiary levels of education. There are four abilities that must be mastered in English; reading, writing, listening, and speaking. Among the four English skills, reading is more emphasized to be taught in Indonesia 
as the item tests of the national examination focused on reading comprehension. Based on the survey results of the English Proficiency Index in 88 countries by English First (EF) as a teaching institute (2018), Indonesia was ranked 51st out of 88 countries in the world.

Whereas Malaysia which is also a developing country and adjacent to Indonesia, was ranked 22nd out of 88 countries, which was on high category of English proficiency. One of the skills measured by EF is reading skill, because the ability to read is one of the abilities that need to be mastered by students in mastering English. According to the survey, the ability of Indonesian learners in English proficiency is in the low category. It is proven that there are still many obstacles faced by students in Indonesia in learning reading comprehension skills, the obstacles are composed of cultural-based issues, English teaching and learning concerns, and social contextual problems (Suryanto, 2017). Beside Indonesia, there are also country such as India, which showed that students exhibited weakness in reading comprehension skill because reading is still considered less important than listening (Balfakeh, 2009).

Reading comprehension of English as a foreign language is an important element towards professional growth, personal development, and academic success (Bashir \& Mattoo, 2012). It is a skill that one must possess in this era of science and advancement (Palani, 2012) for technical and scientific literature are published in English (Bashir \& Mattoo, 2012). These all imply the role of reading comprehension has for students to succeed in their academic journey. In Indonesia the teacher is considered to know everything, and students are required to follow all the teacher's orders. Reading is a process that aims to shape the meaning of a reading (Renn, 1999). According to Sanjaya, et al. (2014), methods in teaching reading skill in every country is different because it depends on the condition and situation of the learners. According to Erlidawati \& Syarfuni (2018) reading is a technique to improve students' ability to extract knowledge and improve students' abilities and success in reading a text. Whereas comprehension in reading is a construction process of students' ability to understand text that is read by taking the meaning of a text and the process involves all elements of the reading process to represent the text in the reader's mind. Reading comprehension activities connect the readers' ideas or thoughts with written text. In other words, the reader will try to associate the knowledge he has in reading with the text he reads. According to Cahyono \& Widiati (2006) skills in reading texts in English for Indonesian learners is an important element of the formation of the English language curriculum in Indonesia.

As quoted by Bahmani \& Farvardin (2017) from Chiang (2015), the reading skill is an important skill to be mastered by foreign language students in the aim of improving their 
language skills. According to Mistar, Zuhairi \& Yanti (2016) in the 1990s, researchers began to be interested in researching learning strategies, especially learning strategies in reading skills. They also quoted from Block (1986), which states that reading strategies is an act of the reader in conceiving a task, what textual cues they attend to, how students understand reading, and the actions they take when they do not understand the contents of the reading. A good learning strategy in reading skills is needed to improve students' ability to read, especially in reading comprehension.

Teaching English reading in Indonesia is to develop comprehension skills. According to Andriani (2016), comprehension is the main goal of reading. Reading activities in secondary classrooms typically focused on searching for main ideas, learning new vocabulary, and emphasising grammatical structure (Lie, 2007; Madya, 2007). Reading comprehension is the main pillar of reading activities, where readers read and figured out the idea of the text. According to Woolley (2011), the purpose of the reading comprehension is to comprehend the overall contents meaning of the reading rather than understanding the meaning of each isolated word or sentences.

According to Carnine, Silber \& Kameenui (1997), behaviors that classified as metacomprehension $\neg$ are; summarizing, paraphrasing, retelling, self-questioning, predicting and verifying, reading aloud and rereading (Mistar, Zuhairi \& Yanti, 2016). In Indonesia, the main use to improve reading comprehension ability in secondary level is summarizing and predicting. The researcher will take those factors as the indicators of this research because those factors is still in a low stage.

In this study, the researcher wants to find out whether Directed Reading-Thinking Activity (DRTA) is a strategy that can guide students in asking questions about a text, making predictions, and then reading to confirm or refute their predictions to achieve the good and enhanced comprehension. And the process is to encourage the students to be active and thoughtful readers (Rahim, 2011).

Based on (Hasan, 2017) who studied about Directed Reading Thinking Activity (DRTA) on Students' Reading Comprehension concluded that there was a significant difference on students' reading comprehension achievement. The student understanding on the specific information aspect in their research improved significantly. Mufidah \& Adi (2016) also added, that the DRTA strategy in their study entitled The Effectiveness of Directed Reading Thinking Activity (DRTA) in Improving the Eleventh Graders 'Reading Comprehension of Analytical Exposition Text had improved students' comprehension. 


\section{LITERATURE REVIEW}

\section{Statement of the Problem}

Based on the previous background of the research, the research problem can be stated as follows:

Is there any significant difference in reading comprehension achievement before and after giving DRTA treatment?

\section{Research Hypotheses}

The hypothesis was tested through the experiment of using DRTA strategy and the statistical studies are hypothesized as follows:

Null Hypothesis (Ho):

There is no significant difference in reading comprehension achievement before and after giving DRTA treatment.

Alternative Hypothesis (Ha):

There is significant difference in reading comprehension achievement before and after giving DRTA treatment

\section{DRTA for Reading Comprehension}

Directed Reading-Thinking Activity (DRTA) is one of the strategies in teaching reading comprehension. DRTA guides the student or reader to predict and prove when the students read the text which DRTA engages the reader with the text. According to (Sari, 2017), DRTA is a way to help readers with abilities that will determine the purpose of reading, the ability to extract, understand and assimilate information, make predictions to check reading material based on the purpose of reading, pass assessment and make decisions based on information obtained from reading material.

According to (Anjani, Jismulatif, \& Masyhur, 2014) quoted from William (2009), DRTA is a strategy that shows the effectiveness of predicting, clarifying, monitoring and evaluating strategies to support reading comprehension activities indirectly. Elfira, Marhum, \& Mashuri (2015) citing Opitz and Lindung (2009) also added that DRTA is a strategy that can improve students' reading comprehension by making transparent predictions made by readers and confirming them when they read. It means that DRTA encourages the reader to use their minds while reading a text. DRTA will guide students to make their own questions based on what they read, then make predictions on the storyline, then continue reading to confirm the truth of their predictions. Through the application of this DRTA, students will be able to share their difficulties in understanding the text. By increasing reading comprehension 
through DRTA, students will be able to answer questions related to the text because they have understood what the author said.

As quoted by Elfira, Marhum \& Mashuri (2015) from Likwise (1998), that DRTA helps students to be more aware to the reading strategies, understanding the reading process, and mastering predictive abilities. Moreover, (Maarof \& Suharjo, 2010) also added that DRTA helps the EFL learners to enhance their understanding of literature in English.

The purpose of reading the DRTA is as follows: (1) give teachers a basic format for introducing systematic learning, (2) increase student understanding, (3) guide students to carry out reading select, (4) improve students' ability to read texts. In (Maarof \& Suharjo, 2010) research, the DRTA technique was able to improve students' reading comprehension because DRTA is an understanding activity that predicts the story, so that it helps students in getting the overall picture they have read. DRTA can attract students' interest in learning especially reading stories and it also shows that the students are not just learning but also preparing themselves for the next life. According to (Cahyono \& Widiati, 2006), teaching English in Indonesia is focusing on reading comprehension. The aim is to improve the skills of students, and it is important to understand the process of reading and obtaining messages, knowledge, or information and reading texts.

According to Haggard (1998) steps in DRTA and advantages of DRTA are as follows: Steps of DRTA:

1. Identifying purposes for reading

2. Adjustment of rate to purposes and material

3. Observing the reading

4. Developing comprehension

5. Fundamental skill development

\section{METHODS}

The research method that used in this study is quantitative research using experimental design. Quantitative research focuses on objective measurement and statistics, mathematics, or numerical analysis of data collected through pretest and posttest by managing statistical data using computer techniques (Babbie, 2010; Muijs, 2010). The researcher gave the pre-test before treatment and post-test after treatment to the students. The aim is to measure the improvement of students' ability in reading comprehension using the method DRTA (Directed Reading Thinking Activity) to enhance students' reading comprehension.

The research design is described in the following table 
Table 1. The research design

\begin{tabular}{ccc}
\hline Pre-test & Treatment & Post-test \\
\hline $\mathrm{O}_{1}$ & $\mathrm{X} 1$ & $\mathrm{O}_{2}$
\end{tabular}

(Purnamasari, 2017)

Explanation,

O1 : Reading Comprehension Test

X1 : Treatment of using DRTA

O2: Post-test after giving a treatment

\section{Population and Sample}

The participants of this study were one class. They are junior high school students in SMPN ADVENT II Bandung, And the sample was Grade VII A which consisted of about 26 students of SMP ADVENT II Bandung.

\section{Research Instrument}

The research adopted this instrument which is used to collect data and information to determine research results. To collect the data of this study the instrument consisted of pilot test, pre-test, treatment, post-test.

\section{Procedure of the Treatment}

The procedure of the treatment is shown below:

For implementing the Directed Reading Thinking Activity (DRTA) according to Slavin (2008:201-204) that is

1. The teacher divides the class into groups of four. Each group is a

2. heterogeneous group.

3. The teacher gives the text or clipping that is suitable with the topic.

4. Students read and work together to find out the main idea, give the suggestion for the text, and write down their opinion about the text on the paper.

5. The students present the result of their group discussion.

6. The teacher and students make the summary.

7. The teacher gives the comments and solution to the students' opinion. 


\section{Post-test}

The post-test was given after giving the treatment. The purpose of the post-test is to measure the level of knowledge of students in reading comprehension after receiving treatment. The post-test is the same as the pre-test.

\section{Data Collection}

To collect data for this study, the researcher administered the pre-test, post-test, did the treatment and scoring. First, the pre-test was given before the treatment to find out their initial achievements before being given the treatment. The second is to do the treatment. The treatment was be conducted using DRTA strategy. After the treatment, the post-test was administered. This aim is to find out the achievement of the class after being given treatment. The pre-test and post-test questions were adopted from previous online National Exams of Junior High School.

\section{Statistic Procedure}

The researcher used the 3 statistical programs in analyzing the data namely SPSS 21.0, Anates, and Microsoft Excel.

\section{Data Analysis}

The researcher used SPSS 21.0 to analyze the data. SPSS is a kind of computer program for statistically computation. It includes test of normalized gain, test of normality, test of variance homogeneity and test of mean difference or T-test. The level of significance $\alpha=0.05$

\section{Normalized Gain}

The normalized gain is to determine the improvement of students' reading comprehension achievement in the experiment by analyzing the results of the pretest and post-test. The following formula that will be used to find out the normalized gain.

$$
\text { g } \frac{\% \text { posttest }-\% \text { pretest }}{100 \%-\% \text { pretest }}
$$

Explanation:
(G)
: mean normalized gain
(\%pre)
: percentage of mean score of pre-test 
(\%post) : : percentage of mean score of post- test

Table2. The Criteria of Normalized Gain:

\begin{tabular}{|c|c|}
\hline Gain $(\mathbf{g})$ & Category \\
\hline $0.71<\mathrm{g} \leq 1.00$ & High \\
\hline $0.31<\mathrm{g} \leq 0.70$ & Moderate \\
\hline $0.00 \leq \mathrm{g} \leq 0.30$ & Low \\
\hline
\end{tabular}

(Hake, 2007)

\section{Normality Test}

Normality test is used to see whether the data obtained from the population are normally distributed or not. To test the normality of the population the researcher used the KolmogorovSmirnov test.

The formula is:

$$
W=\frac{\left(\sum a_{i} x_{i}\right)^{2}}{\sum\left(x_{i}-\bar{x}\right)^{2}}
$$

(Ruseffendi, 1998)

Explanation:

W: Normality test

Xi: sample Data i

ai: The constant obtain from the average value

$\mathrm{x}$ : The average of sample data

\section{Hypothesis Testing}

The hypothesis testing is made to answer the research question. In this study SPSS is being used by the researcher to calculate the result of hypothesis testing which is one sample t-test. Below is the hypothesis:

If $\mathrm{p}$ value (Sig.) $\leq \alpha(0.05)$ then $\mathrm{Ha}$ is accepted, and Ho is rejected. It means there is a significance different in students' interactive reading achievement after using Directed Reading Thinking Activity. 
If $\mathrm{p}$ value (Sig.) $\geq \alpha(0.05)$ then Ho is accepted, and $\mathrm{Ha}$ is rejected. It means there is no significance different in students' interactive reading achievement after using Directed Reading Thinking Activity.

\section{RESULTS AND DISCUSSION}

Description of Students' Reading Achievement

To answer the research questions, the researcher implemented the treatment to one class of grade VII in SMP Advent II Bandung. The class consisted 26 students which is 12 male and 14 female all in one class. The data collected from pretest and posttest of the students were being calculated using SPSS 16. The Table below explained the improvement of students reading ability after giving the treatment. For example, student 1 had an improvement from 66 to 80 . After the data was calculated it was found the mean of the pretest was 50,92 and the mean of the posttest was 86.46 and the gain calculated from both pretest and posttest was 0.715892 . For the clear information please see table below:

Table 3. Recapitulation Table

\begin{tabular}{llll}
\hline Sts & Pre-test & Post-test & Gain \\
\hline S1 & 66 & 80 & 0.4117 \\
S2 & 36 & 66 & 0.4688 \\
S3 & 36 & 93 & 0.8906 \\
S4 & 60 & 93 & 0.8250 \\
S5 & 26 & 96 & 0.9460 \\
S6 & 66 & 96 & 0.8824 \\
S7 & 53 & 96 & 0.9149 \\
S8 & 50 & 96 & 0.9200 \\
S9 & 66 & 93 & 0.7941 \\
S10 & 36 & 93 & 0.8906 \\
S11 & 40 & 90 & 0.8333 \\
S12 & 73 & 90 & 0.6296 \\
S13 & 36 & 63 & 0.4219 \\
S14 & 66 & 90 & 0.7059 \\
S15 & 40 & 90 & 0.8333 \\
S16 & 63 & 93 & 0.8109 \\
S17 & 33 & 93 & 0.8955 \\
S18 & 46 & 93 & 0.8704 \\
S19 & 46 & 63 & 0.3148 \\
S20 & 60 & 93 & 0.8250 \\
S21 & 55 & 93 & 0.8444 \\
S22 & 56 & 96 & 0.9091
\end{tabular}




\begin{tabular}{llll} 
S23 & 40 & 70 & 0.5000 \\
S24 & 60 & 63 & 0.0750 \\
S25 & 65 & 86 & 0.6000 \\
S26 & 50 & 80 & 0.6000 \\
\hline
\end{tabular}

Table 4. Pre-Test, Post Test, Standard Deviation, and Normalized Gain table

\begin{tabular}{ccc}
\cline { 2 - 3 } & & DRTA \\
\cline { 2 - 3 } & Mean & St. Deviation \\
\hline Pre-Test & 50.92 & 13.078 \\
Post Test & 86.46 & 11.514 \\
Normalized & .715892 & .2273412 \\
Gain & & \\
\hline
\end{tabular}

Based on the description above, the mean score in the pre-test is 50.92 and the standard deviation is 13.078. After the treatment was given, it improved in the post test with mean score of 86.46 with gain score 0,715892 and the standard deviation in the post-test is 11.514 with gain 0.2273412 . With the average gain of 0,715892 after doing pretest and the posttest, it can be counted in high category. It can be concluded that there is an improvement on students' reading comprehension ability.

Normality Test

Table 5. One Sample Kolmogorov- Smirnov Test table

\begin{tabular}{llc} 
& & DRTA \\
\hline $\mathrm{N}$ & & 26 \\
Normal Parameter $^{\mathrm{a}}$ & Mean & .715892 \\
& Std. Deviation & $\ldots$ \\
Most Extreme Differences & Absolute & .250 \\
& Positive & .156 \\
& Negative & -.250 \\
Kolmogorov- Smirnov Z & & 1.275 \\
Asymp. Sig. (2-tailed) & & .078 \\
\hline
\end{tabular}

Based on the data on the table above the p-value Sig. is 0.078 which is greater than $\alpha 0.05$. It means that the data used in this study is distributed normally 
Table 6. Test of Homogeneity of Variances table

\begin{tabular}{rrrr}
\hline Pre & & & \\
\hline $\begin{array}{c}\text { Levene } \\
\text { Statistic } \\
1.315\end{array}$ & df1 & df2 & \multicolumn{1}{c}{ Sig. } \\
& & 50 & .257 \\
\hline
\end{tabular}

Homogeneity test is done to find out whether the data obtained has a homogeneous variance or not, homogeneity testing of pre-test and post-test data using the Levene test. Based on the data on the table above the p-value Sig. is 0.257 which is greater than $\alpha 0.05$. It means that the data used in this study is homogenous.

Table 7. One sample t-test table

\begin{tabular}{cccccc}
\hline T & Df & $\begin{array}{l}\text { Sig. (2 } \\
\text { tailed) }\end{array}$ & $\begin{array}{l}\text { Test Value }=0 \\
\text { Mean } \\
\text { Differences }\end{array}$ & $\begin{array}{c}\text { 95\% Confidence } \\
\text { Interval of the } \\
\text { Difference }\end{array}$ \\
\hline 16.057 & 25 & .000 & .7158916 & Lower & Upper \\
& & & & & \\
Gain & & & & .624067 & .807717 \\
\hline
\end{tabular}

One sample test is used to calculate the significance of the research. If $p$ value (Sig.) $\leq \alpha$ $(0.05)$ then ha is accepted and $\mathrm{H} 0$ is rejected If $\mathrm{p}$ value (Sig.) $\geq \alpha(0.05)$. then ha is rejected and $\mathrm{H} 0$ is accepted. In the table below shows the $\mathrm{p}$ value $(\mathrm{Sig})=0.000$ it means that $\mathrm{p}$ value (Sig.) $\leq \alpha(0.05)$ it can be interpreted that $\mathrm{H} 0$ is rejected and Ha accepted. It means there is a significance difference in students' reading achievement after using DRTA.

\section{CONCLUSION}

After interpreting the data, to answer the research question, "Is there any significant difference in reading comprehension achievement before and after giving DRTA treatment?", The researcher concluded that DRTA is an effective strategy in enhancing students' reading ability, because the hypothesis testing result showed that $\mathrm{p}$ value $(\mathrm{Sig})=0.000$, it means that $\mathrm{p}$ value (Sig.) $\leq \alpha(0.05)$. It can be interpreted that $\mathrm{H} 0$ is rejected and Ha accepted. 
From this research, the conclusions that can be drawn is that Directed Reading Thinking Activity is an effective method in improving students' reading skills. It was known in the result of the hypothesis testing showed a significant difference before and after giving treatment.

\section{RECOMENDATIONS}

After conducting the research and making a conclusion, the researcher recommends that future researchers, The English major students, the English teachers and everyone who wants to enhance their reading skills to use DRTA method. From the researcher's personal point of view, the strategy is good to be implemented because most of the students become more active and happier to do their work. This strategy is satisfactory for enhancing reading skills. 


\section{REFERENCES}

Andriani, D. (2016). The Influence of Reading Comprehension Achievement at the Eighth Grade Students of SMP Muhammadiyah 1 Rawa Bening By Using DRTA and KWL Strategies. TELL-US vol.2 no.2, 7-19.

Anjani, S. S., Jismulatif, \& Masyhur. (2014). The Application of DRTA (Directed Reading Thinking Activity) To Improve Reading Comprehension Of Second Grade Students Of Smk Muhahhamdiah 2 Pekanbaru. Pekanbaru: Department of English Education of Riau University 2014.

Aratusa, Z. C. (2017). The Use of Content-Based Summarizing Technique in Improving Students' Reading Skills of Madrasah. Indonesian Journal of English Education, 208220.

Bahmani, R., \& Farvardin, M. T. (2017). Effects of different text difficulty levels on EFL learners' foreign language reading anxiety and reading comprehension. Reading in a Foreign Language Vol.29 No.2, 185-202.

Balfakeh, S. A. (2009, october 10). Problems in Reading Comprehension Skills among Secondary School Students in Yemen. Language In India:Strength for Today and Bright Hope for Tomorrow, 9.

Cahyono, B. Y., \& Widiati, U. (2006). The Teaching Of EFL Reading In The Indonesian Context: The State Of The Art. Teflin Journal Vol.17 No.1, 36-58.

Elfira, Marhum, M., \& Mashuri. (2015). Improving Reading Comprehension Of The Grade VIII Students Through Directed Reading Thinking Activity (DRTA) Strategy. ELTS Vol.3 No.1, 1-11.

Erlidawati, \& Syarfuni. (2018). The Effect of Cooperative Integrated Reading and Composition on Reading Comprehension of IAIN Lhokseumawe, Indonesia. Advances in Language and Literacy Studies Vol.9 No.4, 153-160.

Gilakjani, A. P., \& Sabouri, N. B. (2016). How Can Students Improve Their Reading Comprehension Skill? Journal of Studies in Education Vol.6 No.2, 229-240.

Haggard, M. R. (1988). Developing Critical Thinking with the Directed Reading-Thinking Activity. In M. R. Haggard, The Reading Teacher (pp. 526-533). California: ProQuest Professional Education.

Hasan, A. (2017). The Effect of Directed Reading Thinking Activity (DRTA) Method on Students' Reading Comprehension for State Islamic Senior High School. Journal of English and Arabic Language Teaching Vol.8 No.2, 140-148.

Jones, R. (2001). Summarizing. Charlottesville: Curry School of Education - University of Virginia. 
Khathayut, P., \& Karavi, P. (2011). Summarizing Techniques The Effective Indicators of Reading Comprehension. The 3rd International Conference on Humanities and Social Sciences (pp. 1-12). Hat Yai, Thailand: Faculty of Liberal Arts - Prince of Songkla University.

Lawwill, K. S. (1999). Using Writing-to-Learn Strategies . In K. S. Lawwil, Promoting Peer Collaboration among High School Science Teachers (pp. 29-30). Blacksburg: Virginia Polytechnic Institute and State University.

Lie, A. (2007). Educaton Policy And EFL Curriculum In Indonesia: Between The Commitment To Competence And The Quest For Higher Test Scores. Teflin Journal Vol.18 No.1, 114.

Maarof, N., \& Suharjo, M. K. (2010). Using DRTA Strategy to Overcome EFL Students' Problems in Reading Literature in English. The International Journal of Learning Vol.17 No.8, 93-103.

Madya, S. (2007). Searching For An Approptiate EFL Curriculum Design For The Indonesia Pluraristic Society . Teflin Journal Vol.18 No.2, 196-221.

Marzano, R. J., Pickering, D. J., \& Pollock, J. E. (2001). Classroom Instruction that Works: Research-Based Strategies for Increasing Student Achievement. Association for Supervision and Curriculum Development of Alexandria, 34-42.

Mistar, J., Zuhairi, A., \& Yanti, N. (2016). Strategies Training in the Teaching of Reading Comprehension for EFL Learners in Indonesia. English Language Teaching Vol.9 No.2, 49-56.

Moore, A. L. (2014). Reading Comprehension: Cognitive Skills, Strategies, and Interventions.

Mufidah, Z., \& Adi, N. H. (2016). The Effectiveness of Directed Reading Thinking Activity (DRTA) to Improve the Eleventh Graders' Reading Comprehension of an Analytical Exposition Text. Retain Executive Officer: Head of English Department Of UNESA Vol.4 No.2, 1-10.

Naglieri, J. A., \& Pickering, E. B. (2010). Summarization Strategy for Reading Comprehension. In J. A. Naglieri, \& E. B. Pickering, Helping Children Learn: Intervention Handouts for Use in School and at Home 2nd Edition (pp. 1-2). Baltimore: Paul H. Brookes Publishing Co.,Inc.

Nurhayati, D. A., \& Fitriana, M. W. (2018). Effectiveness of Summarizing in Teaching Reading Comprehension For EFL Students. Indonesian Journal of Language Teaching and Linguistics Vol.3 No. 1, 33-50.

Pecjak, S., \& Pirc, T. (2018). Developing Summarizing Skills in 4th Grade Students: Intervention Programme Effects. International Electronic Journal of Elementary Education Vol. 10 No.5, 571-581.

Renn, C. E. (1999). The Effects of the Directed Reading Thinking Activity on Second Grade Reading Comprehension. Michigan: Grand Valley State University. 
Sanjaya, D., Rahmah, Sinulingga, J., Lubis, A. A., \& Yusuf, M. (2014). Methods of Teaching Reading to EFL Learners: A Case Study. International Journal of Education \& Literacy Studies Vol 2 No.2, 9-14.

Sari, L. (2017). Improving Reading Comprehension Through Directed Reading Thinking Activity (DRTA) Strategy For The Eight Grade Students Of SMP Negeri 17 Medan In The Academic Year Of 2016-2017. Medan: Department of English Education of State Islamic University of North Sumatera.

Stahl, K. A. (2012). Complex Text Or Frustasion-Level Text: Using Shared Reading To Bridge The Difference. The Reading Teacher Vol.66 No.1, 47-51.

Suardi, \& Rahmawati, G. E. (2017). The Use Of Directed Reading Thinking Activity Strategy Through Lesson Study Activity Toward Students Reading Comprehension. Journal on English Language Teaching \& Learning Linguistics and Literature Vol.5 No.2, 146162.

Suryanto. ( 2017, July ). An Investigation On English Reading Comprehension Problems In. The 1st International Conference on Education, Science, Art and Technology (the 1st ICESAT).

Syafi'i, M. L. (2015). Smart Strategy To Boost Students' Reading Comprehension. JEELS Vol.2 No.1, 100-115.

Woolley, G. (2011). Reading Comprehension; Assisting Children with Learning Difficulties. New York: Springer Science \& Business Media.

Wormeli, R. (2005). Summarization in Any Subject. In R. Wormeli, 50 Techniques to Improve Student Learning (pp. 122-123). Alexandria: Association for Supervision and Curriculum Development.

Wulandari, D., Sukirlan, M., \& Sudirman. (2017). Improving Students' Reading Comprehension Of Descriptive Text By Using Prediction Strategy. UNILA Journal of EnglishTeaching 2017, 1-7. 